JOSETA: Journal of Socio Economic on Tropical Agriculture

Volume 1 Nomor 3: 75- 83 Desmber (2019)

JOSETA: Journal of Socio Economic on Tropical Agriculture

http://joseta.faperta.unand.ac.id

ISSN : 2686 - 0953 (Online)

\title{
Analisis Efektivitas Kebijakan Pupuk Bersubsidi Bagi Petani Padi Di Nagari Cupak Kecamatan Gunung Talang Kabupaten Solok \\ Nini Rigi ${ }^{1 *}$, Syahyana Raesi ${ }^{2}$, Rafnel Azhari ${ }^{3}$ \\ ${ }^{1}$ Universitas Andalas, Padang,25163, Indonesia \\ ${ }^{2}$ Fakultas Pertanian, Padang, 25163, Indonesia \\ ${ }^{3}$ Program Studi Agribisnis, Padang, 25163, Indonesia \\ *ninirigi.nr@gmail.com \\ Received: $12^{\text {th }}$ Desember , 2019; 1st Revision: $15^{\text {th }}$ Desmber , 2019; Accepted: $20^{\text {th }}$ Desember, 2019
}

\begin{abstract}
Abstrak
Penelitian ini bertujuan mengetahui prosedur pelaksanaan program pupuk bersubsidi dan menganalisis efektivitas penyaluran pupuk bersubsidi kepada petani padi. Penelitian dilakukan di Nagari Cupak Kecamatan Gunung Talang Kabupaten Solok yang dilaksanakan dari bulan September hingga Oktober 2019. Metode ini dilakukan menggunakan metode survei dan untuk menentukan sampel menggunakan metode purposive sampling. Data dianalisis menggunakan analisis deskriptif dan kualitatif. Hasil penelitian menunjukkan bahwa Prosedur pelaksanaan pupuk subsidi ditempat penelitian yaitu di Nagari Cupak Kecamatan Gunung Talang Kabupaten Solok sudah terlaksana sesuai dengan petunjuk pelaksanaan yang telah ditetapkan. Namun masih ada permasalahan yang terjadi seperti RDKK yang disusun sendiri oleh petani tanpa didampingi oleh penyuluh, berkurangnya keaktifan kelompok tani dalam musywarah untuk menyusun RDKK sehingga RDKK yang digunakan adalah RDKK yang disusun pada tahun sebelumnya. Karena hal ini membuat pengecer juga bisa menggunakan RDKK kelompok tani pada tahun sebelumnya. Kebijakan subsidi pupuk diukur dalam empat indikator tepat, yaitu harga, jenis, waktu, dan jumlah. Berdasarkan keempat indikator tersebut tiga indikator yaitu jenis, waktu dan jumlah dapat dikategorikan efektif, sedangkan untuk indikator tepat harga untuk kebijakan subsidi pupuk belum dapat dikategorikan efektif dikarenakan adanya masalah kesenjangan harga pada pupuk subsidi pada petani, Lini III (distributor) menjual pupuk subsidi diatas HET kepada Lini IV (kios resmi) karena ada tambahan biaya angkut dan bongkar muat. Sehingga menyebabkan pengecer juga menjual pupuk subsidi kepada petani diatas HET.
\end{abstract}

Kata kunci : prosedur, harga, jenis, waktu, jumlah

\section{PENDAHULUAN}

Pertanian memiliki peranan penting dalam perekonomian karena memiliki dampak secara langsung terhadap kebutuhan pokok masyarakat di Indonesia khususnya adalah padi. Padi merupakan bahan makanan pokok bagi masyarakat Indonesia. Kebutuhan bahan makanan pokok di Indonesia tidak pernah menurun, melainkan kian meningkat seiring dengan meningkatnya pertumbuhan jumlah penduduk. Dalam hal mencukupi kebutuhan pokok tersebut (pangan), salah satu cara untuk mengatasi masalah tersebut adalah dengan meningkatkan produktivitas padi. Salah satu upaya untuk meningkatkan hasil produksi padi adalah dengan pengembangan dalam bidang perbenihan.

Pangan merupakan kebutuhan dasar utama bagi manusia yang harus dipenuhi setiap saat. Hak untuk memperoleh pangan merupakan salah satu hak asasi manusia, sebagaimana tersebut dalam pasal 27 UUD 1945 maupun dalam Deklarasi Roma (1996). Pertimbangan tersebut mendasari terbitnya UU No. 7/1996 tentang Pangan. Sebagai kebutuhan dasar dan salah satu hak asasi manusia, pangan mempunyai arti dan 
peran yang sangat penting bagi kehidupan suatu bangsa. Ketersediaan pangan yang lebih kecil dibandingkan kebutuhannya dapat menciptakan ketidak-stabilan ekonomi. Berbagai gejolak sosial dan politik dapat juga terjadi jika ketahanan pangan terganggu. Kondisi pangan yang kritis ini bahkan dapat membahayakan stabilitas ekonomi dan stabilitas nasional.

Salah satu peran pemerintah adalah memberikan subsidi untuk sektor pertanian. Subsidi adalah salah satu bentuk bantuan pemerintah untuk mengurangi beban masyarakat dengan membayar sebagian harga yang seharusnya dibayar oleh masyarakat atau kelompok masyarakat tertentu untuk memberi suatu barang atau jasa menyangkut kepentingan hidup orang banyak. Salah satu subsidi disektor pertanian adalah subsidi pupuk. Pupuk Bersubsidi adalah barang dalam pengawasan yang pengadaan dan penyalurannya mendapat subsidi dari Pemerintah untuk kebutuhan kelompok tani dan/atau petani di sektor pertanian. Pupuk bersubsidi merupakan suatu bantuan yang dikeluarkan oleh pemerintah untuk para petani guna untuk meningkatkan mutu dari hasil pertanian atau perkebunan di Indonesia.

Kebijakan subsidi pupuk juga tidak terlepas dari permasalahan seperti distribusi yang tidak adil dan tidak tepat sasaran, dualisme pasar, penggunaan pupuk yang berlebihan, biaya subsidi yang lebih besar dari manfaat, dan pengawasan. Kurangnya pengawasan dan sanksi bagi para diskriminasi harga yang diterapkan antara subsektor tanaman pangan dan nonpangan, membuka peluang terjadinya aliran pupuk dari subsektor tanaman pangan ke subsektor nonpangan dan juga kecenderungan untuk diekspor. Keadaan ini dapat terlihat dari terjadinya kelangkaan pupuk di sektor tanaman pangan dan peningkatan harga pupuk di pasaran (Haryadi, 2010 dalam Prasetyo, 2017 : 4). Oleh karena itu diperlukan keberhasilan kebijakan pupuk subsidi, Keberhasilan kebijakan ini adalah adanya kecocokan , bila metode pelaksanaan kebijakan dilakukan secara sistematis dalam artian sesuai dengan kebijakan subsidi pupuk, sebaliknya bila pelayanan dan partisipasi masyarakat terhadap kebijakan ini statis, maka perlu adanya perbaikan metode yang lebih baik lagi atau bila perlu kebijakan tersebut dihentikan. Efektivitas pada umumnya digunakan untuk mengukur tingkat keberhasilan dalam melakukan suatu aktivitas atau kegiatan yang dilakukan. Dengan demikian efektivitas merupakan suatu pendekatan yang digunakan untuk melihat tercapai atau tidaknya tujuan atau program yang ditentukan. Dalam penelitian ini peneliti akan melihat keefektifan penyaluran pupuk subsidi tersalurkan atau tidak kepada petani padi. Berdasarkan perumusan masalah yang telah diuraikan di atas maka permasalahan dalam penelitian ini adalah sebagai berikut :

1. Bagaimana prosedur pelaksanaan program pupuk bersubsidi di Nagari Cupak Kecamatan Gunung Talang Kabupaten Solok?

2. Bagaimanakah keefektifan penyaluran pupuk bersubsidi kepada petani padi di Nagari Cupak Kecamatan Gunung Talang Kabupaten Solok ?

Berdasarkan latar belakang dan rumusan masalah yang telah dijabarkan, maka dapat dirumuskan tujuan dari penelitian ini adalah :

1. Mendeskripsikan prosedur pelaksanaan program pupuk bersubsidi di Nagari Cupak Kecamatan Gunung Talang Kabupaten Solok.

2. Menganalisis efektivitas penyaluran pupuk bersubsidi kepada petani padi di Nagari Cupak Kecamatan Gunung Talang Kabupaten Solok.

\section{METODE PENELITIAN}

Data yang dikumpulkan terdiri dari dua jenis, yaitu data primer dan data sekunder yang ada kaitannya dengan permasalahan dalam penelitian ini. Dalam hal ini data primer data yang di ambil dari wawancara dengan petani sampel yaitu petani padi penerima pupuk bersubsidi dengan menggunakan daftar pertanyaan yang telah disiapkan. Sedangkan data sekunder yang dikumpulkan berasal dari Dinas pertanian Kabupaten Solok, Badan Pusat Statistik Kabupaten Solok, BP3K Kecamatan Gunung Talang. Selain itu juga dari literartur yang ada di internet dan buku yang relevan dengan judul penelitian.

Penelitian ini menggunakan metode survei dengan pendekatan kualitatif dan deskriptif. Metode survei adalah penyelidikan yang diadakan untuk memperoleh fakta-fakta dari gejala-gejala yang ada dan mencari keterangan-keterangan secara faktual, baik tentang institusi sosial, ekonomi, politik dari suatu 
kelompok ataupun suatu daerah (Nazir, 1998 : 33). Metode survei membedah dan menguliti serta mengenal masalah-masalah serta mendapatkan pembenaran terhadap keadaan dan praktik-praktik yang sedang berlangsung. Untuk tujuan pertama yaitu mendeskripsikan prosedur pelaksanaan program pupuk bersubsidi di Nagari Cupak Kecamatan Gunung Talang Kabupaten Solok, maka analisis deskriptif, yaitu berusaha untuk menggambarkan atau melukiskan suatu keadaan, atau subyek dan objek penelitian yang berdasarkan fakta-fakta yang ada. Cara yang dilakukan peneliti yaitu dengan cara menulis ulang catatancatatan lapangan yang telah dibuat atau mentranskrip hasil rekaman ketika wawancara dilakukan. Untuk tujuan kedua yaitu menganalisis efektivitas kebijakan pupuk bersubsidi bagi petani padi di Nagari Cupak Kecamatan Gunung Talang Kabupaten Solok, dilihat dari ketepatan harga, ketepatan jumlah, ketepatan jenis, dan ketepatan waktu, maka digunakan analisis deskriptif kualitatif. Untuk mengukur persentase efektivitas, data primer yang berupa jumlah jawaban responden dikumpul dengan menggunakan kuisioner yang disusun dengan menggunakan skala Guttman. Menurut Sugiyono (2014 : 96), pada skala Guttman hanya ada dua interval, misalnya "ya" atau "tidak", "pernah" atau "tidak pernah", "setuju" atau "tidak setuju". Jawaban dapat dibuat skor tertinggi satu dan skor terendah nol. Misalnya untuk jawaban "ya" diberi skor 1 dan "tidak" diberi skor 0 . Untuk cara menyajikan data dari jawaban responden yang berjumlah 60 orang responden tersebut pada tabel, dilakukan berdasarkan perhitungan rata-rata jawaban responden berdasarkan skoring dari setiap jawaban responden. Data yang diperoleh disajikan dengan bentuk tabel dengan tujuan untuk mengetahui persentase dan frekuensi masing-masing alternatif jawaban serta untuk memudahkan dalam membaca data. Jumlah skor ideal (kriterium) untuk seluruh item $=1 \times 60$ = 60 (seandainya semua menjawab "Ya"). Pengukuran ini menggunakan Skala Guttman kemudian dikonversikan kedalam persen (\%) (Sugiyono, 2012 dalam Martatillah, 2018:36) dimana:

$\begin{array}{ll}\text { Jawaban Ya } & : 1 \times 100 \%=100 \% \\ \text { Jawaban Tidak } & : 0 \times 100 \%=0 \%\end{array}$

Persentase akan diperoleh melalui formula sebagai berikut:

$$
\frac{\text { rata }- \text { rata jawaban responden } \times 100 \%}{\text { jumlah jawaban responden }}
$$

Mengenai analisis data angket, data yang telah dipersentasekan kemudian ditentukan persentase angket keseluruhan dengan mengelompokkan data berdasarkan jenis pernyataan, yaitu pernyataan positif dan pernyataan negatif, selanjutnya hasil ditafsirkan dengan menggunakan kategori persentase berdasarkan kriteria penilaian efektivitas.

Tabel 1. Kriteria Penilaian Efektivitas

\begin{tabular}{lr}
\hline \multicolumn{1}{c}{ Interval Persentase Efektivitas $(\mathbf{P})$} & Kriteria \\
\hline $\mathrm{P} \leq 40 \%$ & Sangat Tidak Efektif \\
\hline $40 \% \leq \mathrm{P} \leq 60 \%$ & Tidak Efektif \\
\hline $60 \%<\mathrm{P} \leq 80 \%$ & Cukup Efektif \\
\hline $80 \%<\mathrm{P} \leq 90 \%$ & Efektif \\
\hline $90 \%<\mathrm{P} \leq 100 \%$ & Sangat Efektif \\
\hline
\end{tabular}

Sumber:Sondang,2001:25

\section{HASIL DAN PEMBAHASAN}

\section{Prosedur Pelaksanaan Program Pupuk Bersubsidi}

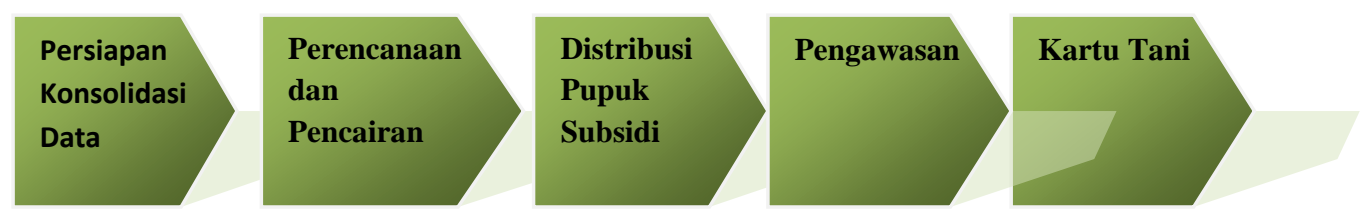

Gambar 1. Alur Prosedur Pelaksanaan Pupuk Subsidi

\section{a. Persiapan Konsolidasi Data}


Persiapan dan konsolidasi data menjelaskan bagaimana transformasi peraturan hingga konsolidasi data dilakukan. Transformasi peraturan dimulai dari merevisi Peraturan Presiden No. 77 tahun 2005 yang diubah dengan Peraturan Presiden No. 15 tahun 2011 tentang Pengawasan Pupuk Bersubsidi. Hal ini perlu dilakukan karena status pupuk bersubsidi yang tidak ada lagi pada mekanisme ini dan diganti kuota pembelian pupuk. Setelah revisi terhadap aturan pupuk bersubsidi sudah selesai ditetapkan, maka Kementerian Pertanian, Kementerian Perdagangan, Kementerian Perindustrian, dan Kementerian Keuangan perlu melakukan harmonisasi peraturan yang sebelumnya membahas mekanisme subsidi pupuk.

Kemudian, Kementerian Pertanian sebagai kementerian teknis menyiapkan data kebutuhan pupuk pada level petani. Sumber data yang digunakan adalah PBDT (Pemutakhiran Basis Data Terpadu) yang dimiliki oleh TNP2K (Tim Nasional Percepatan Penanggulangan Kemiskinan). PBDT (Pemutakhiran Basis Data Terpadu) juga digunakan sebagai sumber data dalam program pemerintah lainnya sehingga program ini dapat lebih tepat sasaran. Dalam menghitung kebutuhan pupuk, Dinas Pertanian Kabupaten/Kota bertindak mengusulkan data kebutuhan pupuk di wilayahnya berdasarkan data PBDT (Pemutakhiran Basis Data Terpadu) dan RDKK (Rencana Defenitif Kebutuhan Kelompok) dengan mengoptimalkan peranan penyuluh dalam memverifikasi kondisi sosial-ekonomi dan lahan yang dimiliki petani.

\section{b. Perencanaan Dan Pencairan}

Kementerian Pertanian menentukan jumlah petani penerima, volume subsidi langsung pupuk kuota, dan jenis pupuk melalui Peraturan Menteri Pertanian. Kebutuhan anggaran final yang sudah dihitung diajukan ke Kementerian Keuangan untuk dilakukan perhitungan serta penyesuaian dengan kemampuan keuangan negara. Anggaran yang sudah disetujui oleh Kementerian Keuangan akan ditransfer ke Produsen sebagai Domestic Market Obligation (DMO) subsidi langsung pupuk kuota melalui KPA (Kuasa Pengguna Anggaran).

\section{c. Distribusi Pupuk Subsidi}

Kementerian Pertanian menunjuk produsen berdasarkan syarat-syarat tertentu dan menunjuk produsen berdasarkan kedekatan geografis produsen dengan daerah yang menjadi tanggung jawabnya. Namun, produsen lain juga dapat diperbolehkan untuk melakukan penyaluran ke daerah lain pada kondisi-kondisi tertentu, misalkan ketika ada produsen yang gagal memenuhi kewajiban dan cadangan pupuk yang tersedia hanya tersisa kurang dari $15 \%$. Produsen kemudian melakukan penunjukkan distributor yang memenuhi syarat tertentu dan selanjutnya pengecer sebagai penyalur atau penjual pupuk pada level petani dan kelompok petani (Poktan). Pengadaan dan penyaluran pupuk bersubsidi dilaksanakan sesuai ketentuan Peraturan Menteri Perdagangan Nomor 15/M-DAG/Per/2015 tentang Pengadaan dan Penyaluran Pupuk Bersubsidi Untuk Sektor Pertanian.Sebagai Pelaksana Subsidi Pupuk yang ditugaskan Pemerintah, PT Pupuk Indonesia (Persero) melaksanakan pengadaan dan penyaluran pupuk bersubsidi melalui produsen, distributor dan penyalur di wilayah tanggung jawab masing-masing.

PT. Pupuk Indonesia (Persero) diberi kewenangan untuk mengatur pembagian wilayah pengadaan dan penyaluran pupuk bersubsidi antar produsen (anak perusahaannya) sesuai dengan kemampuan produksi, dengan tujuan agar dapat lebih fleksibel, efisien dan efektif. Pengadaan dan penyaluran pupuk bersubsidi dilaksanakan melalui produsen kepada distributor (penyalur di Lini III) yang telah ditunjuk di wilayah kerjanya. Selanjutnya distributor menyalurkan kepada Pengecer (penyalur di Lini IV) yang ditunjuk di wilayah kerjanya. Penyaluran pupuk kepada petani/kelompoktani dilakukan oleh pengecer resmi yang telah ditunjuk di wilayah kerjanya.Penyaluran pupuk bersubsidi dilaksanakan dengan sistem tertutup berdasarkan Rencana Definitif Kebutuhan Kelompok (RDKK) dengan Harga Eceran Tertinggi (HET) sebagaimana ditetapkan dalam Peraturan Menteri Pertanian tentang Alokasi dan HET Pupuk Bersubsidi Untuk Sektor Pertanian. Hasil wawancara dengan penyuluh menyatakan bahwa penyusunan RDKK merupakan hasil musyawarah anggota kelompok tani yang didampingi oleh penyuluh. Penyuluh bertugas untuk membuat skenario musyawarah kelompok tani, sehingga mengahasilkan keputusan RDKK yang sesuai dengan rekomendasi anjuran yaitu penggunaan pupuk berimbang $200 \mathrm{~kg} / \mathrm{ha}$. Proses penyusunan RDKK pada tahun-tahun sebelumnya dihadiri oleh semua anggota kelompok tani. Kegiatan yang dilakukan pada saat pertemuan yaitu membahas kebutuhan pupuk bagi anggota kelompok tani, 
diantaranya data luas lahan yang dimiliki dan penggunaan pupuk. Peran penyuluh disini adalah memberikan informasi mengenai pemupukan berimbang. Penyuluh menyatakan bahwa penerapan pupuk berimbang berbeda disetiap daerah karena hal ini dipengaruhi oleh kondisi masing-masing wilayah.

Tabel 2. Perbandingan tahapan penyusunan RDKK pupuk bersubsidi menurut petunjuk pelaksanaan penyusunannya dan di lapangan adalah sebagai berikut:

Proses Penyusunan RDKK Kelompok Tani

\begin{tabular}{|c|c|c|c|c|}
\hline & $\begin{array}{c}\text { Lembang Jao } \\
\text { Mandiri }\end{array}$ & Keterangan & Batali Budi & Keterangan \\
\hline $\begin{array}{l}\text { Penyusunan RDKK pupuk } \\
\text { bersubsidi dilakukan oleh } \\
\text { kelompok tani secara musyawarah } \\
\text { yang dipimpin oleh ketua } \\
\text { kelompok tani dan didampingi oleh } \\
\text { penyuluh pertanian. }\end{array}$ & Tidak sesuai & $\begin{array}{l}\text { Dilakukan sendiri } \\
\text { oleh ketua kelompok } \\
\text { tani/tidak } \\
\text { musyawarah dan } \\
\text { copy paste RDKK } \\
\text { tahun sebelumnya. }\end{array}$ & $\begin{array}{l}\text { Tidak } \\
\text { sesuai }\end{array}$ & $\begin{array}{l}\text { Dilakukan sendiri } \\
\text { oleh ketua kelompok } \\
\text { tani/tidak } \\
\text { musyawarah dan } \\
\text { copy paste RDKK } \\
\text { tahun sebelumnya. }\end{array}$ \\
\hline $\begin{array}{l}\text { RDKK pupuk bersubsidi } \\
\text { dituangkan dalam bentuk sesuai } \\
\text { dengan format dan ditandatangai } \\
\text { oleh ketua kelompok tani }\end{array}$ & Sesuai & $\begin{array}{l}\text { Diisi sesuai format } \\
\text { dan ditandatangani } \\
\text { oleh kelompok tani }\end{array}$ & Sesuai & $\begin{array}{l}\text { Diisi seuai format } \\
\text { dan ditandatangani } \\
\text { oleh kelompok tani }\end{array}$ \\
\hline $\begin{array}{l}\text { Pemeriksaan kelengkapan dan } \\
\text { kebenaran RDKK pupuk bersubsidi } \\
\text { dilakukan oleh penyuluh pertanian } \\
\text { pendamping sebelum disetujui dan } \\
\text { ditandatangani }\end{array}$ & Sesuai & $\begin{array}{l}\text { Pemeriksaan oleh } \\
\text { penyuluh pertanian } \\
\text { pendamping }\end{array}$ & Sesuai & $\begin{array}{l}\text { Pemeriksaan oleh } \\
\text { penyuluh pertanian } \\
\text { pendamping }\end{array}$ \\
\hline $\begin{array}{l}\text { RDKK pupuk bersubsidi yang telah } \\
\text { disusun dibuat } 5 \text { rangkap untuk } \\
\text { pengecer resmi, wali nagari, } \\
\text { penyuluh, ketua gapoktan dan } \\
\text { ketua poktan }\end{array}$ & Sesuai & $\begin{array}{l}\text { Diberikan kepada } \\
\text { pengecer resmi, } \\
\text { penyuluh, dan ketua } \\
\text { poktan }\end{array}$ & Sesuai & $\begin{array}{l}\text { Diberikan kepada } \\
\text { pengecer resmi, wali } \\
\text { nagari, penyuluh, } \\
\text { ketua gapoktan dan } \\
\text { ketua poktan }\end{array}$ \\
\hline
\end{tabular}

\section{Tahap Pengawasan}

Pengawasan terhadap pengadaan dan penyaluran pupuk bersubsidi meliputi jenis, jumlah, harga, tempat, waktu dan mutu. Sebagai mana ditegaskan di dalam Peraturan Presiden Nomor 15 Tahun 2011 tentang Perubahan Atas Peraturan Presiden Nomor 77 Tahun 2005 Tentang Penetapan Pupuk Bersubsidi Sebagai Barang Dalam Pengawasan, maka diperlukan instrumen untuk pelaksanaan pengawasan penyediaan dan penyaluran pupuk bersubsidi. Setiap penyimpangan/pelanggaran terhadap ketentuan pengadaan dan penyaluran pupuk bersubsidi harus ditindak tegas sesuai dengan peraturan perundangundangan yang berlaku.

Ketentuan pelaksanaan pengawasan pengadaan dan penyaluran pupuk bersubsidi sebagaimana tersebut di atas, telah diatur dalam Peraturan Menteri Perdagangan Nomor 15/M-DAG/Per/2015 Tentang Pengadaan dan Penyaluran Pupuk Bersubsidi Untuk Sektor Pertanian, dimana seluruh pihak terkait diharapkan dapat melakukan pengawasan sesuai dengan kewenangannya. Pengawasan pupuk bersubsidi dilakukan oleh seluruh instansi terkait yang tergabung dalam Tim Pengawas Pupuk Bersubsidi Tingkat Pusat maupun oleh Komisi Pengawas Pupuk dan Pestisida (KPPP) tingkat Provinsi dan Kabupaten/Kota. Komitmen dan peran aktif Pemerintah Daerah melalui optimalisasi kinerja KPPP dan Penyidik Pegawai Negeri Sipil (PPNS) di Provinsi dan Kabupaten/Kota dalam pengawalan dan pengawasan terhadap penyaluran dan HET pupuk bersubsidi di wilayahnya, sangat diharapkan untuk menjamin penyaluran pupuk bersubsidi dapat dilaksanakan sesuai prinsip 6 (enam) tepat (jenis, jumlah, harga, tempat, waktu dan mutu).

Dalam pelaksanaan pengawalan penyaluran pupuk bersubsidi sampai ke petani, KPPP juga dibantu oleh Petugas Penyuluh di masing-masing wilayah untuk memantau dan melaporkan kondisi 
dan/atau masa pertanaman. Mekanisme pengawasan pupuk bersubsidi dilakukan dapat dilihat pada tabel dibawah ini.

Tabel 3. Mekanisme pengawasan pupuk bersubsidi

\begin{tabular}{ll}
\hline \multicolumn{1}{c}{ Pengawasan Pupuk Bersubsidi } & Keterangan \\
\hline $\begin{array}{l}\text { Pengawasan oleh Tim/Komisi Pengawasan Pupuk dan Pestisida dilakukan secara periodik (bulanan) } \\
\text { dan sewaktu-waktu apabila diperlukan }\end{array}$ & Terlaksana \\
\hline $\begin{array}{l}\text { Melakukan rapat koordinasi pembahasan perencanaan kebutuhan, penyediaan, penyaluran dan } \\
\text { penggunaan pupuk bersubsidi serta masalah-masalah dilapangan terkait pupuk bersubsidi }\end{array}$ & Terlaksana \\
\hline $\begin{array}{l}\text { Dinas pertanian kabupaten melakukan pengawalan dan pembinaan terhadap pelaksanaan penyaluran } \\
\text { pupuk bersubsidi agar sesuai dengan peruntukkannya salah satunya dengan melakukan pengawalan }\end{array}$ & \\
terhadap pelaksanaan verifikasi dan validasi penyaluran pupuk bersubsidi di tingkat kecamatan & \\
\hline $\begin{array}{l}\text { Semua hasil kegiatan pemantauan, pembinaan dan rapat koordinasi oleh Tim/Komisi Pengawasan } \\
\text { Pupuk dan Pestisida maupun oleh Dinas Pertanian Kabupaten dibuat dalam bentuk laporan. }\end{array}$ \\
\hline \multicolumn{2}{c}{ Berdasarkan tabel diatas, mekanisme pengawasan pupuk bersubsidi di tempat penelitian } \\
terlaksana, walaupun terlaksana namun dilapangan masih ada permasalahan yang terjadi, yaitu penebusan \\
pupuk subsidi masih diatas HET dimana penebusan pupuk subsidi dari pengecer ke distributor diatas \\
HET di karena ada tambahan biaya angkut dan bongkar muat. Sehingga menyebabkan pengecer juga \\
menjual pupuk subsidi kepada petani diatas HET.
\end{tabular}

\section{e. Kartu Tani}

Kartu Tani adalah kartu yang dikeluarkan oleh Perbankan kepada Petani untuk digunakan dalam transaksi penebusan pupuk bersubsidi melalui mesin Electronic Data Capture di pengecer resmi. Sejak tahun 2017 pemerintah mempunyai kebijakan penebusan pupuk subsidi dengan menggunakan Kartu Tani. Tahun 2017 sudah dimulai uji coba pada lima provinsi di Pulau Jawa yaitu : Jawa Barat, Jawa Tengah, Jawa Timur, Banten dan DIY. Pada Tahun 2018 uji coba akan diperluas ke 10 Provinsi yaitu : Sumatera Utara, Sumatera Barat, Sumatera Selatan, Lampung, Aceh, Bali, Nusa Tenggara Barat, Sulawesi Selatan, Kalimanatan Selatan, Kalimantan Barat. Untuk di tempat penelitian belum dilaksanakannya kartu tani hal ini dikarenakan pemerintah belum mengimplementasikan program kartu tani keseluruh Indonesia kerena masalah lokasi petani di wilayah Indonesia yang tidak mudah untuk dijangkau. Selanjutnya kendala distribusi kartu tani juga terdapat pada sistem, karena tidak semua wilayah memiliki akses telekomunikasi dan internet yang baik dan sulitnya Electronic Data Capture (EDC), serta adanya petani belum paham teknologi. Sehingga untuk menyebarluaskan kartu tani, pemerintah akan fokus ke daerah Jawa terlebih dahulu.

\section{Efektivitas Kebijakan Pupuk Subsidi}

a. Efektivitas Ketepatan Harga

Tabel 4. Efektivitas Ketepatan Harga

\begin{tabular}{llrr}
\hline NO. & \multicolumn{1}{c}{ Pernyataan } & \multicolumn{2}{c}{ Jawaban Responden } \\
\cline { 3 - 4 } & \multicolumn{1}{c}{ Ya } & Tidak \\
\hline 1. & Harga pupuk bersubsidi sesuai dengan daya beli & 33 & 27 \\
\hline 2. & Adakah imbalan terhadap penjual (misal bunga) & 14 & 46 \\
\hline 3. & $\begin{array}{l}\text { Mengetahui HET (Harga Ecer Tertinggi) pupuk bersubsidi yang ditetapkan } \\
\text { pemerintah }\end{array}$ & 54 & 6 \\
4. & $\begin{array}{l}\text { Kesesuaian harga yang diberikan pengecer resmi (harga yang diterima } \\
\text { petani) dengan HET (Harga Ecer Tertinggi) }\end{array}$ & 12 & 48 \\
\hline $\mathbf{5 .}$ & Pembelian pupuk subsidi dibayarkan secara tunai & 60 & 0 \\
\hline
\end{tabular}




\begin{tabular}{lrr}
\hline 6. & $\begin{array}{l}\text { Dengan adanya pupuk susbsidi dapat membantu dalam menghemat biaya } \\
\text { berusahatani dan meningkatkan pendapatan }\end{array}$ & 37 \\
\hline Jumlah & $\mathbf{2 1 0}$ & $\mathbf{1 5 0}$ \\
\hline Persentase (100\%) & $\mathbf{5 8 , 3 3}$ & $\mathbf{4 1 , 6 7}$ \\
\hline Kategori & Tidak Efektif & \\
\hline
\end{tabular}

Pupuk bersubsidi yang tersedia di lapangan tidak sesuai dengan HET karena harga jual yang diterima petani tidak sesuai dengan HET yang seharusnya. Dari hasil wawancara dengan anggota kelompok tani beserta pengecer pada wilayah cakupannya diketahui bahwa tingginya harga jual pupuk bersubsidi yang tidak sesuai dengan HET ini disebabkan oleh beberapa faktor, diantaranya biaya yang dikeluarkan pengecer untuk mendapatkan pupuk bersubsidi cukup besar antara lain biaya ongkos, transportasi dan biaya harga tebus pengecer dengan distributor mahal, yaitu pengecer resmi menebus harga pupuk subsidi diatas HET (Harga Ecer Tertinggi). Hal ini yang membuat pengecer resmi menjual pupuk subsidi kepada petani diatas HET.

\section{b. Efektivitas Ketepatan Jenis}

Tabel 5. Efektivitas Ketepatan Jenis

\begin{tabular}{|c|c|c|c|}
\hline \multirow[t]{2}{*}{ No. } & \multirow[t]{2}{*}{ Pernyataan } & \multicolumn{2}{|c|}{ Jawaban Responden } \\
\hline & & Ya & Tidak \\
\hline 1. & $\begin{array}{l}\text { Jenis pupuk yang ditetapkan dalam subsidi pupuk sesuai dengan jenis } \\
\text { pupuk yang diinginkan }\end{array}$ & 60 & 0 \\
\hline 2. & $\begin{array}{l}\text { Kesesuaian jenis pupuk yang dibutuhkan pada RDKK dengan yang } \\
\text { diterima petani }\end{array}$ & 60 & 0 \\
\hline 3. & $\begin{array}{l}\text { Dengan adanya pupuk subsidi dapat memberikan kemudahan dalam } \\
\text { memilih jenis pupuk }\end{array}$ & 60 & 0 \\
\hline \multicolumn{2}{|c|}{ Jumlah } & 180 & $\mathbf{0}$ \\
\hline \multicolumn{2}{|c|}{ Persentase (\%) } & 100 & $\mathbf{0}$ \\
\hline \multicolumn{2}{|c|}{ Kategori } & \multicolumn{2}{|c|}{ Sangat Efektif } \\
\hline
\end{tabular}

Semua jenis pupuk subsidi yaitu Urea, NPK, ZA, SP-36 dan Organik tersedia sesuai dengan jenis yang dibutuhkan petani di lapangan terutama pada saat musim tanam padi.

\section{c. Efektivitas Ketepatan Waktu}

Tabel 6. Efektivitas Ketepatan Waktu

\begin{tabular}{llrr}
\hline \multicolumn{1}{l}{ No. } & Pernyataan & \multicolumn{2}{c}{ Jawaban Responden } \\
\cline { 2 - 4 } & \multicolumn{2}{c}{ Ya } & \multicolumn{1}{c}{ Tidak } \\
\hline $\mathbf{1 .}$ & $\begin{array}{l}\text { Waktu penyerahan/pembagian pupuk bersubsidi selalu tepat pada hari } \\
\text { pembagian }\end{array}$ & 31 & 19 \\
\hline 2. $\quad$ Kesulitan dalam memperoleh pupuk bersubsidi & 42 & 18 \\
\hline Jumlah & $\mathbf{7 3}$ & $\mathbf{7}$ \\
\hline Persentase (\%) & $\mathbf{6 0 , 8 3}$ & $\mathbf{3 9 , 1 7}$ \\
\hline Kriteria & \multicolumn{2}{c}{ Cukup Efektif } \\
\hline
\end{tabular}

Berdasarkan hasil wawancara dengan petani sampel mengatakan bahwa untuk waktu pemakaian pupuk tidak selalu sama dengan petani lain. Perbedaan waktu tersebut berkisar antara satu sampai dua minggu, sehingga pembelian yang dilakukan ke kios juga tidak sama dengan petani lain.

Berdasarkan wawancara dengan pengecer dapat disimpulkan bahwa tidak ada kendala terkait dengan waktu pemakaian pupuk oleh petani. Hal ini dikarenakan pupuk dijatah setiap bulannya sesuai dengan ketentuan pemerintah Dengan kata lain pupuk disalurkan oleh Distributor kepada pengecer setiap bulannya. Kondisi seperti ini memperlihatkan bahwa indikator tepat waktu terlaksana dengan baik sesuai dengan ketentuan pemerintah. Pupuk bersubsidi tersedia di lapangan sesuai dengan waktu musim tanam padi. Tidak ada kendala keterlambatan karena pupuk disalurkan oleh distributor ke pengecer setiap bulan. 


\section{d. Efektivitas Ketepatan Jumlah}

Tabel 7. Efektivitas Ketepatan Jumlah

\begin{tabular}{|c|c|c|c|}
\hline \multirow[t]{2}{*}{ No. } & \multirow[t]{2}{*}{ Pertanyaan } & \multicolumn{2}{|c|}{ Jawaban Responden } \\
\hline & & Ya & Tidak \\
\hline 1. & Kesesuaian jumlah pupuk subsidi dengan RDKK yang diajukan & 34 & 26 \\
\hline 2. & Kesesuaian jumlah pupuk subsidi dengan yang diterima petani & 33 & 27 \\
\hline 3. & $\begin{array}{l}\text { Dengan adanya pupuk bersubsidi dapat mencukupi kebutuhan pupuk } \\
\text { untuk produksi padi }\end{array}$ & 44 & 16 \\
\hline \multicolumn{2}{|r|}{ Jumlah } & 111 & 69 \\
\hline \multicolumn{2}{|c|}{ Persentase (\%) } & 61,67 & $\mathbf{3 8 , 3 3}$ \\
\hline \multicolumn{2}{|c|}{ Kategori } & \multicolumn{2}{|c|}{ Cukup Efektif } \\
\hline
\end{tabular}

Berdasarkan hasil wawancara dengan petani sampel bahwa penggunaan pupuk di lapangan tidak selalu dalam jumlah yang sama dikarenakan tidak semua petani sampel menggunakan pupuk sesuai dengan jumlah yang telah diusulkan dalam RDKK.

\section{KESIMPULAN}

Prosedur Pelaksanaan Pupuk Subsidi ditempat penelitian yaitu di Nagari Cupak Kecamatan Gunung Talang Kabupaten Solok sudah terlaksana sesuai dengan petunjuk pelaksanaan yang telah ditetapkan. Namun masih ada permasalahan yang terjadi seperti RDKK yang disusun sendiri oleh petani tanpa didampingi oleh penyuluh, berkurangnya keaktifan kelompok tani dalam musywarah untuk menyusun RDKK sehingga RDKK yang digunakan adalah RDKK yang disusun pada tahun sebelumnya. Karena hal ini membuat pengecer juga bisa menggunakan RDKK kelompok tani pada tahun sebelumnya.

Kebijakan subsidi pupuk diukur dalam empat indikator tepat, yaitu harga, jenis, waktu, dan jumlah. Berdasarkan keempat indikator tersebut tiga indikator yaitu jenis, waktu dan jumlah dapat dikategorikan efektif, sedangkan untuk indikator tepat harga untuk kebijakan subsidi pupuk belum dapat dikategorikan efektif dikarenakan adanya masalah kesenjangan harga pada pupuk subsidi pada petani, Lini III (distributor) menjual pupuk subsidi diatas HET kepada Lini IV (kios resmi) karena ada tambahan biaya angkut dan bongkar muat. Sehingga menyebabkan pengecer juga menjual pupuk subsidi kepada petani diatas HET.

Pemerintah harus memperbaiki mekanisme penyaluran subsidi pupuk seperti meberikan sanksi kepada para oknum karena masih ada oknum-oknum yang memanfaatkan pupuk subsidi untuk kepentingan mereka. Perbaikan ini terutama dalam kaitannya dengan tepat harga dimana sebaiknya pemberian subsidi pupuk lebih dekat kepada sasaran atau target penerima subsidi pupuk. Perbaikan mekanisme penyaluran penting terkait adanya harga yang tidak sesuai dengan HET dikarenakan adanya masalah kesenjangan harga pada pupuk subsidi pada petani, Lini III (distributor) dan Lini IV (kios resmi). Penyuluh harus memberikan informasi tentang pupuk subsidi agar petani tidak dikelabui oleh pengecer resmi dan selalu mendampingi petani dalam menyusun RDKK.

\section{UCAPAN TERIMA KASIH}

Ucapan terima kasih disampaikan kepada petani dan pihak-pihak terkait lainnya yang telah memberikan data dan informasi yang diperlukan untuk penelitian ini. Ucapan terimakasih juga disampaikan kepada pembimbing Dosen Prodi Agribisnis yang telah membimbing selama pelaksanaan penelitian.

\section{Daftar Pustaka}


Nazir, Mohammad. 1998. Metode Penelitian. Jakarta : Ghalia Indonesia

Prasetyo, Andri dkk. 2017. Analisis Efektivitas Kebijakan Subsidi Pupuk Dan Pengaruhnya Terhadap Produksi Dan Pendapatan Petani Padi Sawah. Sumatera Utara: Universitas Sumatera Utara

Sugiyono, 2014. Metode Penelitian kuantitaif, Kualitatif, dan R/D. Bandung: Alfabet 